\title{
COMMUNITY BASED TOURISM DEVELOPMENT IN BELITUNG REGENCY BANGKA BELITUNG ISLAND PROVINCE
}

\author{
Arnapis Jambak \\ Master Program of Geography Education Faculty of Social Science, Universitas Negeri Padang \\ arnapis.jambak90@gmail.com
}

\begin{abstract}
The purpose of this research was to identify readiness and ways to increase community prosperity in Belitung Regency through the concept of society based tourism development. By the tourism product offered, thus the most appropriate way was promoting the original characters of Belitung Regency community in tourism product development strategy and then developing the development framework, so that tourism activities in Belitung Regency can be a form of sustainable tourism. In order to support the objective, improving the quality of community should be a major concern, so that the community would be able to create tourism products that have competitive and comparative qualities in international market and able to improve and facilitate community potential and tourism potential in Belitung regency to improve the community prosperity which has been relying on the income from mining sector.
\end{abstract}

Keywords: Tourism, community, development, sustainable

\section{Introduction}

Wealth of Natural Resources (WNR) of Indonesia is not for the question. However, it became one of the biggest challenges out of so many challenges this nation has was to manage the potential of its wealth of natural resources itself. Indonesia has 17.504 islands which are potential to become area for tourism development. The development of a regional tourism will have positive impacts or negative impacts. The impacts will affect the physical condition and the social and economic life of population around the sights. This imbalance occurs because most of large-scale tourism business was monopolized by the upper class businessmen, where this type of tourism businesses set a variety of specific standards for every aspect of its activities ${ }^{1}$.

Indonesia has diversity in tourism which in existence very potential. This relates to the condition of most of the tourism objects are still beautiful in order to be optimized for tourism. Tourism is not only to generate the income of the country but also to provide benefits for the region, as well as the people living in the surrounding area of the tourist destination. Demartoto ${ }^{2}$ suggests some forms of alternative tourism products that have the potential to be developed such as

\footnotetext{
1 Muliawan, H. 2000. "Perencanaan dan Pengembangan Desa Wisata Stuppa: Indonesia". Makalah.

2 Demartoto, Argyo. 2009. Pembangunan Pariwisata Berbasis Masyarakat dalam Pendidikan. Yogyakarta: Pustaka Pelajar.
} 
cultural tourism, ecotourism, marine tourism, adventure tourism, agro tourism, rural tourism, spiritual tourism, gastronomy and others.

The development of tourism is essentially an effort to develop and utilize objects and tourism attractions in the form of natural beauty, flora and fauna diversity, pluralism and cultural traditions, as well as relics of ancient history. The diversity of objects and tourism attraction becomes an important asset to create tourism activities which can have positive effects on the development of the region, as well as to be able to gain foreign exchange, employing many people, with income fee that stimulate the regional economy thus improve the living standards. This then becomes the spirit of the central government and local government to promote tourism, by repairing and improving the existing facilities and makes the tourism sectors as alternative options which can contribute in increasing regional revenue and scommunity prosperity.

Community based tourism is an approach that emphasizes the development of tourism on the local community either directly or not directly involved in the tourism industry ${ }^{3}$. It is implemented by providing opportunities (access) in the management and development of tourism that led to the political empowerment through a more democratic life including the share of the profits from tourism activities which are more equitable for local communities. This idea is conveyed to criticize the development of tourism which often ignores the participation of local community in tourism destinations. The concept of community based tourism is the basis of sustainable tourism development which confirms that the community is no longer the object of development but as a determinant of the development itself ${ }^{4}$.

Belitung regency is one of the main tourist destinations in Indonesia for its famous nautical tourism. Not only has the appeal of natural lanndscapes, Belitung regency also has socio-cultural diversity and customs. For tourists, it can be an alternative because it has unique tourism potential. The attractiveness this tourism object has is the presence of the customs that are still strong and the existence of historical heritage such as the oldest temple, the lighthouse and the Sheik funeral area around the regency.

However, the main challenge is the lack of sufficient capacity in the community to independently manage local development, including the development of tourism destinations. Meanwhile, the Department of Culture and Tourism of Belitung regency government has begun to show its support for the development of tourism in this region. One of which was improved condition for the access to the site of Tourism to support the development of tourism potential that can give more value. The current development tourism is not able to improve the prosperity of the community. Many people are not involved, neither directly

\footnotetext{
3 Hausler, Nicole dan Strasdas, Wolfgang. 2003. "Training Manual For Community Based Tourism". In WEnt, Zschoutau.

${ }^{4}$ Ardika, I Wayan. 2004. "Pariwisata Bali: Membangun Pariwisata-Budaya dan Mengendalikan Budaya Pariwisata”. Bali Menuju Jagadhita: Aneka Perspektif. Denpasar: Pustaka Bali Post, halaman 20-33.
} 
nor indirectly in tourism activities. This is partly due to the lack of community understanding about the business opportunities offered by the tourism activities.

It is necessary to conduct an assessment of tourism development that involves local communities. With the community based tourism development, community participation directly on tourism development seems more real, from planning, implementation and monitoring. This study aims to assess the suitability of Belitung regency in developing community based tourism.

\section{Method}

Data collection techniques to be performed in this study is in several ways:: 1) In depth interviews with relevant government authorities, tourism experts, tour operators, tourists, as well as experts/private sector who contribute and have the attention to the community and the development of tourism and especially to the local people. 2) Field observations in order to make observations and checks on the tourism product in terms of attractions, amenitas and accessibility, market (tourists) as well as on community involvement in tourism. 3) Observation of secondary data such as the identification of the supporting factors which include accommodation, facilities, accessibility, facilities and infrastructure. Method used for data analysis was descriptive qualitative research paradigm based on related theories. Using community based tourism Keywordss in Belitung regency.

\section{Results and Discussion}

Data collection activities are carried out at 23 to 31 July, 2016 in order to Field Study and Reseach of Geography research in Belitung regency Bangka Belitung Island Province. The results of this research were as follows :

\section{Community Readiness in Community Based Tourism Development}

Belitung regency with the capital Tanjung Pandan which is part of the Bangka Belitung Province known as its Rainbow Warriors Land, was the island which donated the largest amount of foreign exchange at that time to the country from tin mining result. Nowadays, Belitung regency was known to be an area of tourist destinations that has the potential to nautical tourism such as: Cape Coast Kelayang, Cape Coast Tinggi, Cape Coast Pendam, Sand Beach, Cape Lancur, Lengkuas Island, Bird Island, Sand Island, Kepayang Island, Lebong Island, the Rock Sailing Island. In addition, there are also other toursm objetcs such as: Belitung District Government Museum, Badau Museum, Belitong traditional house, Baginde Stone, Gusong Bugis, Fishermans Village Tanjung Binga and Bali Village.

The readiness of the community in the development of community-based tourism can be seen from the factors supporting the development of tourism in Belitung regency which is supported by the facility of Has. Hanandjoeddin Airport, lodging and restaurant services, travel agency, startegic pathway that links between districts, as well as the adequate communications. However, the existence of other problems faced because of the needs analysis which has not 
been implemented regarding the adequate market's need such as : promotion of regional or national, as well as other supporting facilities.

Some concepts of a regional approach taken were based on prority:

1. Superior region, in the sense of a region with a rare tourism objects, as well as a strong tourist attraction. In addition, it was not found in other regions, and has been tested by both domestic and international travel market and capable on providing rapid and thorough development.

2. Mainstay region, a region with stong tourism objects and tourist attraction, has a strong position in the regional scope, as well as has a strong domestic market and began to be offered on the international market, thus has economy contribution on the scale of Bangka Belitung.

3. Development area, is a tourist area with a future attraction and already have a potential market.

To support that all kind of tourism uses optimally environmental resources, both natural resources and community, respecting the authenticity of local culture, provide economic benefits for the long term, and provide a high quality experience to the traveler as well as maintaining a satisfaction. For that reason some of the measures to be taken includes making the community as well as host travelers. This means that the people around tourist sites have to be involved and participate actively, so that it could be efficient and effective, not only for the self prosperity, family and for the improvement of tourism development.

The basic principle of the development of community based tourism was putting the community as the major stakeholders by empowering the community in a variety of tourism activities, so that the use of tourism was as much as possible for the sake of the general community. The main targets of tourism development was to improve the prosperity of local communities.

Therefore, in the development of community based tourism, local governments need to socialize the concept of tourism to the community who lived at tourism objects with the involvement of experts in their respective fields. In order to achieve understanding of the development of community based tourism, to minimize the posibility of misunderstanding in planning tourism development.

\section{Criteria for Community-Based Tourism}

\section{1) Economic Criteria}

In accordance with the formulation of criteria for community based tourism development, tourism activities should be able to contribute to local economic development and improve the welfare of local communities, such as: (1) opens Opportunities and Work With New Economic Activity, (2) not Eliminate Existing Economic Activity, (3) creating Economic Relations Between Sectors, (4) improve living standards and provide benefits to local communities, (5) contributes to Community Work, (6) provides Market for Engaging Community in the Promotion of Goods and Service Travel, and (7) improving the Quality of Infrastructure and Public Facilities

\section{2) Social and Culture Criteria}


Social and cultural criteria look more at community involvement in every stage of tourism activities. In accordance with the formulation of criteria for the development of community based tourism, will be discussed as follows: (1) involving People in Every Stage Planning, (2) creating Educational Opportunities For Local Communities, (3) supporting the Role of Public Agencies, (4) creating Community Pride and Community Ownership to Tourism, (5) preserving Cultural Uniqueness and Local Characteristics, (6) add Value and Local Culture, (7) offering goods and services which Responsible to Social Life and Environment of the Tourism.

\section{3) Environmental Criteria}

To ensure the sustainability of tourism development, the environment is an extremely important factor. In this study environmental criteria are divided into four: (1) using Natural Resources Sustainably, but Not Exploiting them, (2) minimize the Environmental Impact, (3) improve the Conservation of Natural Resources and Environment, (4) reflecting the Monitoring result to Ensure Sustainability and Environmental Balance and Resources.

\section{Suitability Analysis of Tourism in Belitung For Community Based Tourism}

Criteria for community based tourism development were divided into 3 main criteria, economic criteria, socio - cultural, and environmental. Analysis of suitability criteria for the development of community based tourism in Belitung regency was done in a way, which described the results of the analysis of primary and secondary data as well as qualitative analysis and observations from questionnaires and interviews. The data collection is done by triangulation technique, whereby the observation, interviews, and the collection of documents were done at once. Data collection techniques with interviews with specific figures related to the research objectives. Information of important figures was needed because they were the party that were institutionally authorized on the development of tourism and the condition of cpmmunity in the region. Besides doing interviews with community leaders, also there was giving questionnaires to the community and tourists, with population sample gather from community respondents gathered by using cluster sampling while for tourist respondents by using sequential simple random sampling. Field observations are intended to provide an objective identification of various physical resources both natural and artificial form of tourism stocks in Belitung regency. Besides that, there was also observation done on community main activity in Belitung regency. There was also gathering data/information regarding the development of communite based tourism through several literature, legal documents, planning documents, as well as studies that have been done before. 
Table 1. Tourism Appropriateness Grouping of Belitung Regency with the Criteria of Community Based Tourism Development

\begin{tabular}{|c|c|c|c|}
\hline Criteria & Appropriate & Almost Appropriate & Not Appropriate \\
\hline Economic & $\begin{array}{ll}\checkmark & \text { Not eliminating } \\
& \text { existing economic } \\
& \text { activities } \\
\checkmark & \text { Creating } \\
& \text { relationships } \\
& \text { between sectors } \\
\checkmark & \text { Contributing to } \\
& \text { community } \\
& \text { activities } \\
\checkmark & \text { Improving the } \\
& \text { quality of } \\
\text { infrastructure and } & \text { public facilities }\end{array}$ & $\begin{array}{ll}\checkmark & \text { Opening } \\
\text { opportunities and } \\
\text { work with new } \\
\text { economic activity } \\
\checkmark \quad \text { Improving the } \\
\text { standard of living } \\
\text { and provide } \\
\text { benefits to local } \\
\text { communities }\end{array}$ & $\begin{array}{l}\checkmark \checkmark \text { Providing market } \\
\text { to engage the } \\
\text { community in the } \\
\text { promotion of } \\
\text { goods and travel } \\
\text { services }\end{array}$ \\
\hline $\begin{array}{l}\text { Social- } \\
\text { Culture }\end{array}$ & 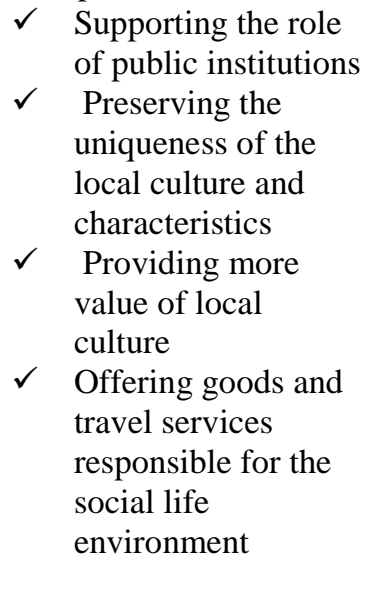 & & $\begin{array}{ll}\checkmark & \text { Involving the } \\
\text { community in } \\
\text { every stage of } \\
\text { planning } \\
\checkmark \text { Creating } \\
\text { educational and } \\
\text { training } \\
\text { opportunities for } \\
\text { local people } \\
\checkmark \text { Creating } \\
\text { community pride } \\
\text { and a sense of } \\
\text { community } \\
\text { ownership of } \\
\text { tourism. }\end{array}$ \\
\hline $\begin{array}{l}\text { Environ- } \\
\text { mental }\end{array}$ & $\begin{array}{ll}\checkmark & \text { Utilizing natural } \\
& \text { resources in a } \\
& \text { sustainable manner, } \\
& \text { but not exploiting } \\
& \text { them } \\
\checkmark & \text { Minimizing } \\
\text { environmental } \\
\text { impacts }\end{array}$ & $\begin{array}{ll}\checkmark & \text { Improving } \\
\text { conservation of } \\
\text { natural resources } \\
\text { and the } \\
\text { environment } \\
\checkmark \quad \text { Reflecting the } \\
\text { results of } \\
\text { monitoring to } \\
\text { ensure the } \\
\text { sustainability and } \\
\text { environmental } \\
\text { balance and } \\
\text { resources. }\end{array}$ & \\
\hline
\end{tabular}

Source: Analysis Result, 2016

Criteria for the development of community based tourism were grouped as in Table I. From these groupings, the obtained results indicated that in general, the tourism condition in Belitung regency was almost appropriate in accordance with 
the criteria of community based tourism. This will facilitate the recommendations formulation for the development of community based tourism in Belitung regency.

The development of community based tourism in Belitung regency, based on the readiness of society and criteria of tourism, which can be done through two strategies: The first strategy is to design a variety of tourism products such as program tourist packages, such as tour guide, the destination to small islands, snorkeling and also visiting historical places (museums, temple, lighthouse, and funerals of indigenous leaders). The second strategy is to improve the ability, skills and competencies of the community in order to manage the tourism, because the community based tourism itself becomes a major role in its management.

Community based tourism activities can proceed smoothly if it is supported by competent human resources. Activities that can be done to improve human resources includes training local people a guide, tour guide, lodge manager of travel and training which produces handicrafts that can make certain characteristics of Belitung regency itself.

These tourism activities should be supported by the local community participation. Whether in the form of understanding, support, and management should be improved for the sake of the successful development of tourism programs offered. Increasing readiness and capability for the management of community based tourism. Not only trained for skills, people should also be equipped with language skills. Another thing that must be done is to increase the ability of management to run consistently. Tourism Appropriateness of Belitung regency with the criteria of community based tourism analyzed from community perception, interviews with community leaders, manage tourist facilities, government agencies and local communities.

\section{Conclusion}

Based on the results of the analysis, it can be concluded that the conditions of Belitung regency is now has been a community based, although not optimal, therefore, in the development of community based tourism in the Belitung regency need to be prioritize the criteria which are not fulfilled, so the development of community based tourism in Belitung regency will be implemented optimally, where tourism activities can increase the welfare of the community while still preserving the natural environment of Belitung regency. With the tourism products as offered, the most appropriate action is to raise the original characters of Belitung community in tourism products development strategy, and then arrange the framework of its development based on tourism products, so that the tourism activities in Belitung regency can be a form of sustainable tourism. Supporting the improvement of the quality of community should be a major concern, for example, to conduct training or counseling about how to generate more value of training products related to the development of tourism, which in turn can create tourism products that have competitive and comparative qualities in the international market. 


\section{REFERENCE}

Ardika, I Wayan. 2004. "Pariwisata Bali: Membangun Pariwisata-Budaya dan Mengendalikan Budaya Pariwisata". Bali Menuju Jagadhita: Aneka Perspektif. Denpasar: Pustaka Bali Post, halaman 20-33.

Demartoto, Argyo. 2009. Pembangunan Pariwisata Berbasis Masyarakat dalam Pendidikan. Yogyakarta: Pustaka Pelajar.

Hausler, Nicole dan Strasdas, Wolfgang. 2003. "Training Manual For Community Based Tourism". In WEnt, Zschoutau.

Muliawan, H. 2000. "Perencanaan dan Pengembangan Desa Wisata Stuppa: Indonesia". Makalah.

Undang-Undang RI No. 10 Tahun 2009 Tentang Kepariwisataan

Pemerintah District of Belitung. RTRW District of Belitung 2014 - 2034.

Pemerintah District of Belitung. Data Sekunder Belitung dalam Angka. 2015 